\title{
Peningkatan Hasil Belajar Pendidikan Agama Islam tentang Menerima Qada' dan Qadar melalui Pendekatan Saintifik bagi Siswa Kelas VI di SD Inpres 33 Kabupaten Sorong
}

\author{
Syaida \\ SD Inpres 33 Kabupaten Sorong \\ email: syaida2019@gmail.com
}

\begin{abstract}
Abstrak: Penelitian ini bertujuan untuk mengetahui Peningkatan Hasil Belajar Pendidikan Agama Islam Sub tema Menerima Qada' Dan Qadar Melalui Pendekatan Saintifik. Subyek penelitian adalah seluruh siswa kelas VI pada Semester Genap Tahun Pelajaran 2015/2016 dengan siswa sebanyak 20 orang, terdiri dari 9 orang laki-laki dan 11 orang perempuan. Pada pelaksanaannya yang terdiri dari 2 siklus, yaitu siklus I dilaksanakan selama empat kali pertemuan dan Siklus II dilaksanakan selama empat kali pertemuan. Pengumpulan data dilaksanakan dengan menggunakan Tes Akhir Siklus dan Observasi. Adapun langkahlangkah yang ditempuh adalah sebagai berikut: Pertama, guru menyampaikan tujuan dari materi yang akan dipelajari dan memotivasi siswa belajar. Kedua, guru menyajikan materi secara umum dengan pendekatan Saintifik. Ketiga, guru membimbing siswa untuk mengerjakan tugas. Keempat, guru memberikan evaluasi setelah mengerjakan tugas. Data yang terkumpul dianalisis dengan menggunakan analisis kualitatif dan kuantitatif. Hasil belajar Pendidikan Agama Islam siswa kelas VI pada Semester Genap Tahun Pelajaran 2015/2016 meningkat setelah dilakukan pembelajaran dengan pendekatan saintifik selama dua siklus dengan hasil sebagai berikut : (1) Hasil belajar Pendidikan Agama Islam siswa sebelum pembelajaran dengan pendekatan Saintifik berada dalam kategori rendah dengan nilai rata-rata 62,5 dari nilai tertinggi 70 dan nilai terendah 50. (2) Hasil belajar Agama siswa setelah pembelajaran Siklus I dengan pendekatan saintifik dengan nilai rata-rata 72.5 dari nilai tertinggi 90 dan nilai terendah 60. (3). Hasil belajar Agama siswa setelah pembelajaran dengan pendekatan Saintifik Siklus II berada dalam kategori sedang dengan nilai rata-rata 84,5 dari nilai tertinggi 100 dan nilai terendah 65. (4) Terjadi peningkatan kehadiran siswa dalam kegiatan belajar mengajar, dan (5) Terjadi peningkatan motivasi belajar Pendidikan Agama Islam.

Kata Kunci : hasil belajar, pendekatan saintifik, Qada' dan Qadar
\end{abstract}

Abstract: This study aims to determine the Improvement of Learning Outcomes in Islamic Religious Education Sub-themes of Receiving Qada 'and Qadar Through the Scientific Approach. The research subjects were all sixth grade students in the Even Semester 2015/2016 Academic Year with as many as 20 students, onsisting of 9 men and 11 women. In its implementation consisting of 2 cycles, namely cycle I was held for four meetings and Cycle II was held for four meetings. Data retrieval is done by using Cycle and Observation Final Tests. The steps taken are as follows: First, the teacher conveys the purpose of the material to be studied and motivates students to learn. Second, the teacher presents the material in general with a Scientific approach. Third, the teacher guides students to work on the task. And fourth, the teacher provides an evaluation after doing the assignment. The collected data was analyzed using qualitative and quantitative analysis. Learning outcomes of Islamic education for Grade 6 students in the Even Semester 2015/2016 Academic Year increased after learning with a scientific approach for two cycles with the following results: (1) Student Islamic Education learning outcomes before learning with the Scientific approach in the low category with an average value of 62.5 from the highest score of 70 and the lowest value of 50. (2) Religious learning outcomes of students after Cycle I learning with a scientific approach with an average value of 72.5 from the highest score of 90 and the lowest value 60. (3). Religious learning outcomes of students after learning with the Scientific approach Cycle II are in the moderate category with an average value of 84.5 from the highest score of 100 and the lowest value 65. (4) There is an increase in the presence of students in teaching and learning activities, and (5) An increase motivation to learn Islamic student education.

Keywords: learning outcomes, scinetific approach, Qada' and Qadar 


\section{Pendahuluan}

Pendidikan Agama Islam merupakan ilmu yang melandasi perkembangan iman, taqwa, kepribadian, membentukan karakter untuk dapat memfilter perkembangan teknologi modern, mempunyai peran penting dalam berbagai disiplin dan memajukan daya pikir manusia, sebagaimana tertulis dalam Peraturan Menteri Pendidikan Nasional Nomor 22 tahun 2006 tentang Standar Isi. Mata pelajaran Pendidikan Agama Islam perlu diberikan kepada semua peserta didik yang beragama Islam mulai dari sekolah dasar untuk membekali peserta didik dengan kemampuan berpikir logis, analitis, sistematis, kritis, dan kreatif, serta kemampuan bekerjasama. Kompetensi tersebut diperlukan agar peserta didik dapat memiliki kemampuan memperoleh, mengelola, dan memanfaatkan informasi untuk bertahan hidup pada keadaan yang selalu berubah, tidak pasti, dan kompetitif.

Kompetensi dasar Pendidikan Agama Islam disusun sebagai landasan pembelajaran untuk mengembangkan kemampuan tersebut di atas. Selain itu dimaksudkan pula untuk mengembangkan kemampuan menerapkan Pendidikan Agama Islam dalam pemecahan masalah dan mengkomunikasikan ide atau gagasan dalam kehidupan sehari-hari. Pendekatan saintifik merupakan fokus dalam pembelajaran Pendidikan Agama Islam yang mencakup masalah tertutup dengan solusi tunggal, masalah terbuka dengan solusi tidak tunggal, dan masalah dengan berbagai cara penyelesaian. Untuk meningkatkan kemampuan memecahkan masalah perlu dikembangkan keterampilan memahami masalah, membuat model Pendidikan Agama Islam, menyelesaikan masalah, dan menafsirkan solusinya.

Pembelajaran Pendidikan Agama Islam hendaknya diawali dengan pengenalan masalah yang sesuai dengan situasi. Dengan mengajukan masalah kontekstual, peserta didik secara bertahap dibimbing untuk menguasai konsep Pendidikan Agama Islam. Untuk meningkatkan keefektifan pembelajaran, sekolah diharapkan menggunakan pendekatan saintifik, teknologi informasi dan komunikasi seperti komputer, alat peraga, atau media lainnya.

Kenyataannya yang terjadi di SD Inpres 33 Kabupaten Sorong, dengan kriteria ketuntasan minimal untuk mata pelajaran Pendidikan Agama Islam Kelas VI adalah 70. Penulis mulai mengajar di SD Inpres 33 sejak tahun 1997 dan ditugaskan mengajar di kelas VI. Saat penulis mengajar dijumpai siswa sulit memahami materi menerima Qada' dan Qadar. Hal tersebut disebabkan salah satunya karena dalam menyajikan materi pelajaran hanya bersifat abstrak, guru hanya menjelaskan, mencatat, dan dilanjutkan dengan mengerjakan soal latihan, sehingga siswa sulit untuk membayangkan dan membawa ke dalam dunia nyata atau pada hal-hal konkrit dalam kehidupan sehari-hari yang pada akhirnya siswa kurang tertarik pada mata pelajaran Pendidikan Agama Islam sehingga berakibat rendahnya prestasi/hasil belajar Pendidikan Agama Islam khususnya sub tema Menerima Qada' Dan Qadar. Berdasarkan uraian di atas maka penulis tertarik untuk melakukan penelitian dengan mengambil judul: " Meningkatkan Hasil Belajar Pendidikan Agama Islam Sub tema Menerima Qada' dan Qadar Melalui Pendekatan Saintifik Bagi Siswa Kelas VI Di SD Inpres 33 Kabupaten Sorong"

\section{Metode Penelitian}

Penelitian ini merupakan penelitian tindakan kelas (classroom action research), yaitu pencermatan terhadap kegiatan belajar berupa sebuah tindakan, yang sengaja dimunculkan dan terjadi dalam sebuah kelas secara bersama. Penelitian ini dilakukan secara kolaboratif dan partisipatif. Dalam penelitian tindakan kelas ini, guru bertindak sebagai pelaksana tindakan, sedangkan guru sejawat bertindak sebagai kolaborator.

Penelitian dilaksanakan di SD Inpres 33 Kabupaten Sorong yang beralamat di Jalan Poros Katapop Distrik Salawati Kabupaten Sorong. Pemilihan SD Inpres 33 Kabupaten Sorong, karena 
belum dimanfaatkannya pendekatan saintifik untuk pembelajaran pada Pendidikan Agama Islam. Waktu Penelitian ini dilaksanakan pada tanggal 8 Januari sampai dengan 20 April 2016. Subyek dalam penelitian ini adalah siswa kelas VI SD Inpres 33 Kabupaten Sorong. Sedangkan yang menjadi objek penelitian adalah hasil belajar Pendidikan Pendidikan Agama Islam dengan pemanfaatan pendekatan Saintifik. Peneliti memilih siswa kelas VI karena belum mencapai KKM (70) untuk mata pelajaran Pendidikan Pendidikan Agama Islam khususnya pada sub tema Menerima Qada' dan Qadar.

Teknik Pengumpulan Data yang digunakan yaitu 1). Observasi (Observation) adalah suatu teknik yang dilakukan dengan cara mengadakan pengamatan secara teliti serta pencatatan secara sistematis, 2) Wawancara adalah alat pengumpulan informasi dengan cara mengajukan sejumlah pertanyaan secara verbal kepada orang-orang yang dianggap dapat memberikan informasi atau penjelasan mengenai hal-hal yang dianggap perlu, 3) Tes adalah suatu percobaan yang diadakan untuk mengetahui ada atau tidaknya hasil-hasil pelajaran tertentu pada seseorang murid atau kelompok, dan 4) Teknik Dokumentasi digunakan untuk mendapatkan data mengenai kegiatan yang terjadi selama pembelajaran berlangsung.

Pemeriksaan keabsahan data digunakan untuk mengecek kebenaran data yang dihasilkan oleh peneliti, sehingga dapat diperoleh data yang valid serta dapat dipertanggungjawabkan keabsahannya. Untuk dapat mengetahui keabsahan data dalam penelitian, peneliti menggunakan teknik triangulasi. Penelitian ini dilakukan dalam bentuk siklus, masing-masing siklus terdiri dari perencanaan, tindakan, pengamatan, dan refleksi. Penelitian ini didesain sebagai Penelitian Tindakan Kelas (PTK) yang akan dilakukan dengan beberapa siklus. Adapun siklusnya dapat digambarkan sebagai berikut :

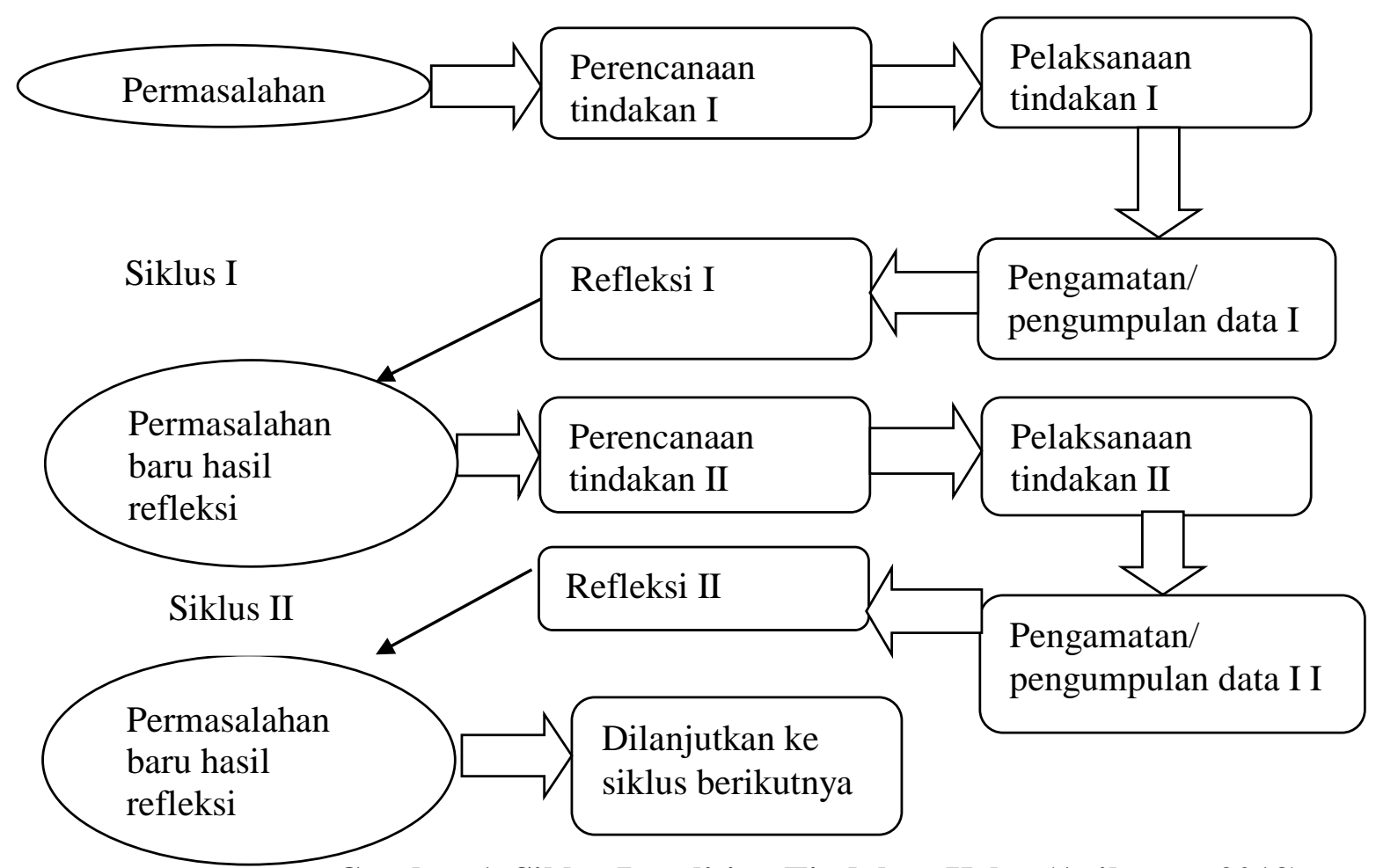

Gambar 1. Siklus Penelitian Tindakan Kelas (Arikunto, 2013) 


\section{Hasil dan Pembahasan}

\subsection{Kondisi Awal dan Perencanaan}

Hasil pengamatan yang dilakukan oleh peneliti, prestasi belajar pada mata pelajaran Pendidikan Pendidikan Agama Islam sub tema Menerima Qada' dan Qadar siswa Kelas VI SD Inpres 33 Kabupaten Sorong dikatakan rendah karena masih ada 10 siswa yang nilainya di bawah 70 yang merupakan Kriteria Ketuntasan Minimal (KKM) yang telah ditentukan sekolah dengan melihat hasil ulangan harian. Hal ini disebabkan guru masih menggunakan metode ceramah, sehingga siswa menjadi pasif dan kurang aktif dalam mengikuti proses pembelajaran. Hal ini apabila tidak ditindaklanjuti tentu mengakibatkan proses pembelajaran tidak optimal dan mempengaruhi prestasi belajar.

Agar mempermudah dalam pelaksanaan tindakan maka perlu dibuat suatu perencanaan. Perencanaan yang dibuat meliputi: membuat RPP dengan materi yang diajarkan dengan pendekatan saintifik, membuat lembar observasi untuk mengamati partisipasi aktif siswa dalam mengikuti pembelajaran, membuat soal tes, menyiapkan media pembelajaran yang akan digunakan, dan alat peraga yang digunakan dalam rangka mencapai tujuan pembelajaran.

Melalui perencanaan sebelum melakukan tindakan akan mempermudah dalam menentukan keberhasilan tindakan yang dilaksanakan. Perencanaan dapat dijadikan panduan pelaksanaan tindakan, sehingga penelitian yang dilakukan tidak jauh melenceng dari tujuan penelitian untuk menerapkan sebuah media pembelajaran pendekatan saintifik dalam rangka meningkatkan partisipasi aktif siswa dan prestasi belajar siswa.

\subsection{Hasil Tindakan}

\section{a. Siklus I}

\section{1) Perencanaan Tindakan}

Perencanaan tindakan yang dilakukan pada siklus I adalah sebagai berikut: a). Menyiapkan materi pelajaran dengan pendekatan saintifik; b). Membuat Rencana Pelaksanaan Pembelajaran (RPP) tentang materi yang akan diajarkan. Rencana Pelaksanaan Pembelajaran ini disusun sebagai pedoman peneliti dalam melaksanakan kegiatan pembelajaran di dalam kelas, c). Menyusun dan mempersiapkan lembar observasi untuk mengetahui partisipasi siswa selama proses pembelajaran berlangsung. Lembar observasi ini digunakan sebagai pedoman peneliti di dalam mengamati siswa di kelas. Lembar ini akan diisi pada setiap pertemuan dan dibuat oleh peneliti, d). Menyusun dan mempersiapkan soal-soal yang digunakan untuk mengukur prestasi belajar siswa setelah proses pembelajaran menggunakan pendekatan saintifik berlangsung (post test), dan e). Mempersiapkan alat dan media yang akan digunakan untukproses pembelajaran di kelas.

\section{2) Pelaksanaan Tindakan}

a. Pertemuan ke-1

Langkah - langkah pelaksanaan tindakan pada siklus I pertemuan ke-1 adalah sebagai berikut:

(1) Kegiatan awal: Guru mengucapkan salam, Guru mengecek presensi siswa, Guru menyampaikan apersepsi yang berhubungan dengan materi yang akan disampaikan, Guru memberikan motivasi kepada siswa dengan memberi pertanyaan kepada siswa, dan Guru menyampaikan kompetensi dasar dan tujuan yang ingin dicapai yaitu mengenai materi yang akan diajarkan.

(2) Kegiatan inti: Guru menyampaikan materi tentang menerima Qada' dan Qadar, Guru memberi contoh sikap dan tindakan menerima qada' dan qadar dalam kehidupan sehari-hari, Siswa mengerjakan soal latihan dan berdiskusi dengan teman 
sebangkunya, dan Siswa yang telah selesai mengerjakan soal latihan, presentasi di depan kelas.

(3) Penutup: Siswa dengan dibimbing dan difasilitasi guru menyimpulkan materi yang telah disampaikan, Guru memberikan tugas rumah guna mempersiapkan materi yang akan datang, Guru memberikan informasi bahwa akan ada tes untuk pertemuan berikutnya, Guru menutup kegiatan pembelajaran dengan berdo'a dan Guru mengucapkan salam.

b. Pertemuan ke-2

Langkah - langkah pelaksanaan tindakan pada siklus I pertemuan ke-2 adalah sebagai berikut:

(1) Kegiatan awal: Guru mengucapkan salam, Guru mengecek presensi siswa, Guru memberikan apersepsi yang berhubungan dengan materi yang akan disampaikan, Guru memberikan motivasi kepada siswa dengan memberi pertanyaan kepada siswa, dan Guru menympaikan kompetensi dasar dan tujuan yangingin dicapai yaitu mengenai materi yang akan diajarkan.

(2) Kegiatan inti: Guru menyampaikan tentang menerima Qada' dan Qadar, Guru memberi contoh menerima Qada' dan Qadar dengan hal yang nyata dalam kehidupan sehari-hari, Guru memberi soal latihan yang dikaitkan dengan kehidupan sehari-hari, Siswa mengerjakan soal latihan dan berdiskusi dengan teman sebangkunya, Siswa yang telah selesai mengerjakan soal latihan, presentasi di depan, dan Siswa dan guru berdiskusi tentang jawaban di maksud.

(3) Penutup: Siswa dengan dibimbing dan difasilitasi guru menyimpulkan materi yang telah disampaikan, Guru memberikan post test, Guru memberikan tugas guna mempersiapkan materi yang akan datang, Guru menutup kegiatan pembelajaran dengan berdo'a, dan Guru mengucapkan salam.

\section{3) Hasil Observasi}

Selama kegiatan belajar mengajar berlangsung observer melakukan pengamatan secara langsung mengenai partisipasi yang ditunjukkan oleh siswa dalam mata pelajaran Pendidikan Agama Islam. Dalam penelitian ini, unsur-unsur yang termasuk dalam partisipasi siswa atau keaktifan siswa meliputi mendengarkan penjelasan Guru, mencatat penjelasan guru, memperhatikan pembelajaran, bertanya, menjawab pertanyaan, mengeluarkan pendapat, menghargai pendapat teman, refleksi/menjelaskan kembali. Maka dari indikator-indikator tersebut, hasil dari lembar pengamatannya sebagai berikut:

\section{Tabel 1. Hasil Observasi Partisipasi Aktif Siswa pada Siklus 1}

\begin{tabular}{lccc}
\hline \multicolumn{1}{c}{ Aspek yang diamati } & $\begin{array}{c}\text { Jumlah siswa } \\
\text { total }\end{array}$ & $\begin{array}{c}\text { Partisipasi Aktif } \\
\text { Jumlah siswa }\end{array}$ & \begin{tabular}{c} 
Persentase (\%) \\
\hline Mendengarkan Penjelasan
\end{tabular} \\
Mencatat penjelasan & 20 & 7 & 35 \\
Memperhatikan pembelajaran & 20 & 10 & 50 \\
Bertanya & 20 & 10 & 50 \\
Menjawab pertanyaan & 20 & 2 & 10 \\
Mengeluarkan pendapat & 20 & 2 & 20 \\
Menghargai pendapat teman & 20 & 4 & 10 \\
Mampu menjelaskan kembali & 20 & 1 & 20 \\
\hline
\end{tabular}

\section{4) Hasil Tes}


Berdasarkan data diatas dapat kita lihat, sebelum perbaikan rata-rata sebesar 62,5, sedangkan pada siklus1 dapat diketahui sebesar 72,5. Hal ini menunjukkan bahwa terjadi peningkatan hasil belajar siswa setelah menggunakan pendekatan saintifik pada mata pelajaran Pendidikan Pendidikan Agama Islam. Namun berdasarkan nilai siswa pada siklus I di atas, kriteria keberhasilan belum tercapai, karena masih terdapat 10 siswa belum mencapai KKM, sehingga perlu dilanjutkan dengan siklus berikutnya yaitu siklus II.

\section{5) Refleksi}

Dalam pembelajaran pada siklus I ini, tahap refleksi dilakukan oleh peneliti dan guru sejawat untuk mengevaluasi hasil observasi partisipasi aktif siswa dan hasil dari pelaksanaan post test sebagai umpan balik setelah pembelajaran. Penggunaan pendekatan saintifik meskipun belum maksimal, sebenarnya sudah menunjukkan partisipasi aktif siswa. Masih banyak siswa yang cenderung enggan untuk mengemukakan pendapat dan hal tersebut dikarenakan siswa belum terbiasa di dalam pembelajaran menggunakan pendekatan saintifik, sehingga masih banyak siswa yang pasif dalam mengikuti pembelajaran. Prestasi belajar pada siklus I juga belum menunjukkan hasil yang maksimal, meskipun telah banyak siswa yang memenuhi kriteria ketuntasan minimal tetapi masih ada juga siswa yang belum memenuhi.

Berdasarkan hasil refleksi tersebut, maka perlu adanya tindakan lanjutan untuk memperbaiki atau menyempurnakan pembelajaran dengan menggunakan pendekatan saintifik. Dikarenakan belum tercapainya target tindakan yang diinginkan pada pelaksanaan tindakan pada siklus I, maka peneliti dan guru sejawat sepakat untuk melanjutkan tindakan pada siklus II.

\section{b. Siklus II}

\section{1) Perencanaan Tindakan}

Perencanaan tindakan yang dilakukan pada siklus II adalah sebagai berikut: a). Membuat materi yang akan diajarkan dengan menggunakan pendekatan saintifik, b). Membuat Rencana Pelaksanaan Pembelajaran (RPP) tentangmateri yang akan diajarkan. Rencana Pelaksanaan Pembelajaran ini disusun sebagai pedoman guru atau peneliti dalam melaksanakan kegiatan pembelajaran di dalam kelas, c). Menyusun dan mempersiapkan lembar observasi untuk mengetahui partisipasi siswa selama proses pembelajaran berlangsung. Lembar observasi ini digunakan sebagai pedoman peneliti di dalam mengamati siswa di kelas. Lembar ini akan diisi pada setiap pertemuan dan dibuat oleh peneliti dengan dikonsultasikan pada guru dan dosen pembimbing, d). Menyusun dan mempersiapkan soal-soal yang digunakan untukmengukur prestasi belajar siswa setelah proses pembelajaran menggunakan pendekatan saintifik berlangsung (post test), dan e). Mempersiapkan alat dan media yang akan digunakan untukproses pembelajaran di kelas.

\section{2) Pelaksanaan Tindakan}

Langkah - langkah pelaksanaan tindakan pada siklus II pertemuan ke-1 adalah sebagai berikut: (1). Kegiatan awal: Guru mengucapkan salam, Guru mengecek presensi siswa, Guru memberikan apersepsi yang berhubungan dengan materi yang akan disampaikan, Guru memberikan motivasi kepada siswa dengan memberikan pertanyaan kepada siswa, Guru menympaikan kompetensi dasar dan tujuan yangingin dicapai yaitu mengenai materi yang akan diajarkan, (2). Kegiatan inti: guru menyampaikan tentang Menerima Qada' dan Qadar anjuran Q,S. Al-Maidah dan Q.S. Al-Hujurat, Guru memberi contoh sikap dan tindakan menerima qada' dan qadar dalam kehidupan sehari-hari, Siswa membaca ayat-ayat tersebut dengan tartil, Guru memberi soal latihan yang dikaitkan 
dengan kehidupan sehari-hari, Siswa mengerjakan soal latihan dan berdiskusi dengan teman sebangkunya, Siswa yang telah selesai mengerjakan soal latihan, presentasi di depan kelas dan Siswa dan guru berdiskusi tentang jawaban di maksud, dan (3) Penutup: Siswa menyimpulkan materi pelajaran dengan difsilitasi guru, Guru memberikan tugas rumah kepada siswa untuk mempersiapkan materi selanjutnya, Guru memberikan informasi bahwa pertemuan selanjutnya akan diadakan tes, Guru menutup kegiatan pembelajaran dengan berdo'a, dan Guru mengucapkan salam.

Langkah - langkah pelaksanaan tindakan pada siklus II pertemuan ke-2 adalah sebagai berikut: (1) Kegiatan awal: Guru mengucapkan salam, Guru mengecek presensi siswa, Guru menyampaikan apersepsi yang berhubungan dengan materi yang akan disampaikan, Guru memberikan motivasi kepada siswa dengan memberikan pertanyaan kepada siswa, dan Guru menympaikan kompetensi dasar dan tujuan yangingin dicapai yaitu mengenai materi yang akan diajarkan, (2). Kegiatan inti: Guru menyampaikan tentang Menerima Qada' dan Qadar anjuran Q,S. Al-Maidah dan Q.S. Al-Hujurat, Guru memberi contoh sikap dan tindakan menerima qada' dan qadar dalam kehidupan seharihari, Siswa membaca ayat-ayat tersebut dengan tartil, Guru memberi soal latihan yang dikaitkan dengan kehidupan sehari-hari, Siswa mengerjakan soal latihan dan berdiskusi dengan teman sebangkunya, Siswa yang telah selesai mengerjakan soal latihan, presentasi di depan kelas, dan Siswa dan guru berdiskusi tentang jawaban dimaksud, dan (3). Penutup: Siswa dengan dibimbing dan difasilitasi guru menyimpulkan materi yang telah disampaikan, guru memberikan post test, Guru menutup kegiatan pembelajaran dengan berdo'a, dan Guru mengucapkan salam.

\section{3) Pengamatan terhadap partisipasi aktif siswa (observasi)}

Pada siklus II ini tingkat partisipasi aktif siswa sudah mulai menunjukkan adanya peningkatan yang relatif stabil dan hampir semua siswa sudah memperhatikan, berpartisipasi dan mengikuti proses pembelajaran. Hasil dari pengamatan siswa pada siklus II, dapat dilihat pada tabel berikut ini:

Tabel 2. Hasil Observasi Partisipasi Aktif Siswa pada Siklus 1I

\begin{tabular}{lccc}
\hline \multirow{2}{*}{ Aspek yang diamati } & Jumlah siswa & \multicolumn{2}{c}{ Partisipasi Aktif } \\
\cline { 3 - 4 } & total & Jumlah siswa & Persentase \\
\hline Mendengarkan Penjelasan & 20 & 18 & 90 \\
Mencatat penjelasan & 20 & 18 & 90 \\
Memperhatikan pembelajaran & 20 & 18 & 90 \\
Bertanya & 20 & 6 & 30 \\
Menjawab pertanyaan & 20 & 8 & 40 \\
Mengeluarkan Pendapat & 20 & 4 & 20 \\
Menghargai Pendapat teman & 20 & 10 & 50 \\
Mampu menjelaskan kembali & 20 & 4 & 20 \\
\hline
\end{tabular}

\section{4) Hasil Tes}

Berdasarkan rata-rata hasil belajar antara tes pada siklus I dan siklus II yang diketahui bahwa pada tes II mencapai rata-rata sebesar 84,5 mempunyai rata-rata lebih tinggi dibandingkan dengan rata-rata pada tes yang dilakukan di siklus 1 sebesar 72,5. Hal ini menunjukkan adanya terjadi peningkatan pada hasil belajar pada siklus II dalam mata pelajaran Pendidikan Pendidikan Agama Islam. Berdasarkan rata-rata pada siklus II di atas, kriteria keberhasilan sudah tercapai karena lebih dari $85 \%$ siswa telah mencapai 
KKM, bahkan 90\% siswa mencapai KKM ( 70 ), hal ini menunjukkan adanya pencapaian tingkat keberhasilan sesuai dengan kriteria keberhasilan yang telah ditetapkan.

\section{5) Refleksi}

Pada tahap refleksi peneliti bersama guru mengevaluasi hasil dari tes dan observasi, dari hasil pengamatan dan refleksi di siklus II maka penerapan pendekatan saintifik dapat meningkatkan partisipasi aktif dan prestasi belajar siswa. Pada hasil partisipasi aktif siswa, siswa telah berpartisipasi secara aktif dalam pembelajaran dan keaktifan siswa pada proses pembelajan berlangsung dapat dilihat pada dokumentasi berupa foto-foto yang telah terlampir dalam lampiran, sedangkan pada hasil belajar semua siswa sudah mencapai ketuntasan yang telah ditetapkan yaitu memperoleh nilai $\geq 70$ untuk masing-masing siswa pada siklus ke II yaitu mencapai rata-rata 84,5 . Jadi dari hasil pengamatan dan refleksi di siklus II penggunaan pendekatan saintifik dapat meningkatkan partisipasi aktif dan prestasi belajar siswa.Hal ini dikarenakan dengan menggunakan pendekatan saintifik, siswa lebih tertarik dan mempunyai motivasi yang tinggi untuk belajar.Keunggulan yang ada perlu dipertahankan untuk mendukung peningkatan dalam penggunaan media pembelajaran selanjutnya.Sedangkan beberapa kelemahan dalam media pembelajaran audio visual perlu diperbaiki untuk pertemuan selanjutnya.Berdasarkan hasil tes dan hasil observasi dari siklus II yang telah terjadi peningkatan dari siklus I, peneliti dan guru sepakat bahwa penelitian ini tidak dilanjutkan ke siklus III.

\subsection{Pembahasan}

Dalam penelitian ini, pembahasan lebih difokuskan pada pelaksanaan penelitian tindakan kelas menggunakan pendekatan saintifik, peningkatan partisipasi aktif pada siswa, dan peningkatan prestasi belajar siswa dalam mata pelajaran Pendidikan Pendidikan Agama Islam.

\section{Pelaksanaan Penelitian Tindakan Kelas Menggunakan Pendekatan Saintifik}

Pelaksanaan pendekatan saintifik untuk meningkatkan partisipasi aktif dan prestasi belajar siswa dilakukan dalam dua siklus dan dilaksanakan dalam empat pertemuan di kelas.Penerapan pendekatan saintifik pada siklus I dilakukan dalam dua kali pertemuan, tetapi di dalam pelaksanaannya belum tercipta peningkatan partisipasi aktif dan prestasi belajar siswa secara maksimal, maka peneliti sepakat untuk melanjutkan pada siklus berikutnya yaitu siklus II. Siklus demi siklus terbentuk untuk memberikan perbaikan dan perbandingan di dalam pembelajaran agar partisipasi aktif dan prestasi belajar lebih meningkat sesuai dengan apa yang diharapkan peneliti.

Dari pernyataan tersebut dapat disimpulkan bahwa mata pelajaran Pendidikan Pendidikan Agama Islam dengan menggunakan pendekatan saintifik ini dapat memberi kemudahan bagi siswa dalam memahami materi yang diberikan guru. Dalam pembelajaran siklus I masih ada siswa yang kurang dapat memahami materi pelajaran, permasalahan yang diberikan oleh guru serta belum semua siswa menunjukkan partisipasi aktif selama proses pembelajaran dengan menggunakan pendekatan saintifik ini. Akan tetapi setelah siklus II para siswa berangsur-angsur dapat memahami materi, serta hampir semua siswa berpartisipasi aktif selama proses pembelajaran dengan menggunakan pendekatan saintifik. Untuk menilai kriteria keberhasilan prestasi belajar siswa, peneliti menggunakan kriteria ketuntasan minimal (KKM) yang ditetapkan.Dalam mengadakan penilaian peneliti mengukur keberhasilan prestasi siswa menggunakan soal setelah tindakan dilakukan. 


\section{Pembahasan Partisipasi Aktif Siswa}

Hasil penelitian tindakan siklus I dan II dengan penggunaan pendekatan saintifik menunjukkan adanya peningkatan terhadap aktivitas belajar siswa. Peningkatan terjadi pada observasi siklus II di mana dalam observasi ini yang diamati adalah partisipasi aktif siswa. Dari hasil observasi diperoleh data aktivitas siswa sebagai berikut:

Tabel 3. Peningkatan Partisipasi Aktif Siklus I dan Siklus II

\begin{tabular}{llcc}
\hline \multirow{2}{*}{ No } & \multicolumn{1}{c}{ Indikator } & \multicolumn{2}{c}{ Siklus } \\
\cline { 3 - 4 } & & $\mathrm{I}(\%)$ & $\mathrm{II}(\%)$ \\
\hline 1 & Mendengarkan Penjelasan & 33 & 40 \\
2 & Mencatat penjelasan & 40 & 50 \\
3 & Memperhatikan pembelajaran & 36 & 43 \\
4 & Bertanya & 6 & 16 \\
5 & Menjawab pertanyaan & 12 & 23 \\
6 & Mengeluarkan Pendapat & 6 & 10 \\
7 & Menghargai Pendapat teman & 12 & 20 \\
8 & Mampu menjelaskan kembali & 3 & 10 \\
\hline & $\quad$ Jumlah & 148 & 212 \\
& $\quad$ Rata-Rata & 18,5 & 26,5 \\
\hline
\end{tabular}

Jadi dapat disimpulkan bahwa dengan penggunaan pendekatan saintifik dalam mata pelajaran Pendidikan Pendidikan Agama Islamdapat meningkatkan partisipasi aktif siswa dalam proses pembelajaran.

\section{Pembahasan Prestasi Belajar Siswa}

Setelah dilakukan penelitian yang dimulai dari tahapan siklus I, sampai pada tahapan siklus II dapat dilihat adanya peningkatan partisipasi aktif dan prestasi belajar siswa dengan menggunakan pendekatan saintifik. Berdasarkan pemaparan prestasi belajar di atas dapat diberikan penjelasan bahwa telah terjadi peningkatan prestasi belajar siswa dari siklus I ke siklus II. Dapat disimpulkan bahwa dengan penggunaan pendekatan saintifik pada mata pelajaran Pendidikan Agama Islam dapat meningkatkan prestasi belajar siswa. Peningkatan prestasi belajar dapat dilihat pada diagram sebagai berikut:

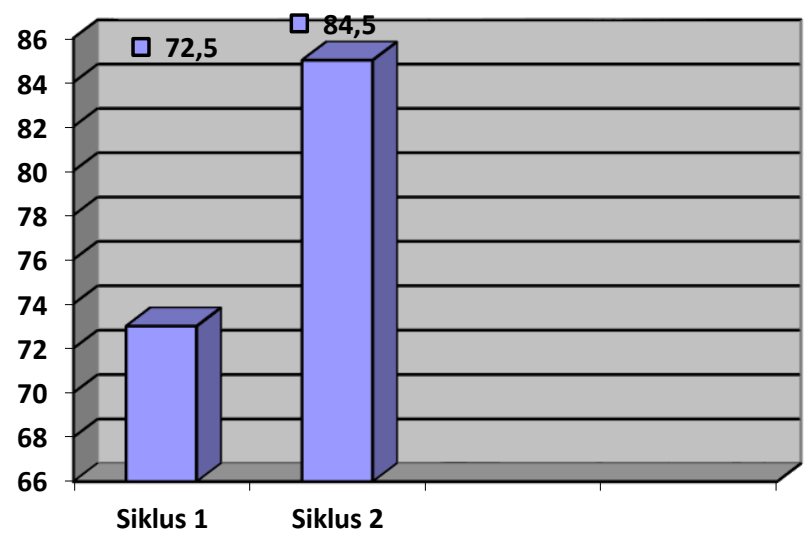

Gambar 2. Diagram Nilai Rata-Rata Kelas 


\section{Kesimpulan dan Implikasi \\ 4.1. Kesimpulan}

Berdasarkan hasil analisis data dan pembahasan yang telah peneliti lakukan, aktivitas belajar siswakelas V di SD Inpres 33 Kabupaten Soronguntuk mata pelajaran Pendidikan Agama Islam, dapat ditarik kesimpulan sebagai berikut:1). Penerapan pembelajaran dengan menggunakan pendekatan saintifik dapat meningkatkan hasil belajar Pendidikan Agama Islam pada siswa sub tema Menerima Qada' dan Qadar kelas VI dilihat dari adanya peningkatan persentase rata-rata kelas, persentase ketuntasan siswa dan perolehan nilai tertinggi;2). Peningkatannya dapat dilihat dari hasil observasi pada siklus I dan siklus II. Pada aspek mendengarkan penjelasan siklus I ke siklus II. Begitupun pada aspek mencatat, memperhatikan pembelajaran, aspek bertanya, aspek menjawab pertanyaan, aspek mengeluarkan pendapat, aspek menghargai pendapat, aspek mampu menjelaskan kembali. Hal ini menunjukkan bahwa terjadi peningkatan terhadap partisipasi aktif siswa pada pembelajaran dengan pendekatan saintifik yang diterapkan pada kelas VI di SD Inpres 33 Kabupaten Sorong; dan 3). Pendekatan saintifik juga dapat meningkatkan hasil belajar pada mata pelajaran Pendidikan Agama Islam di kelas VI di SD Inpres 33 Kabupaten Sorong. Peningkatan hasil belajar ini dapat dilihat dari adanya perubahan nilai rata-rata yang diperoleh siswa pada setiap akhir siklus. Nilai rata-rata yang diperoleh siswa pada siklus I sebesar 72,5 dan siklus II sebesar 84.5. Hal tersebut membuktikan bahwa dengan menggunakan pendekatan saintifik dapat meningkatkan prestasi belajar siswa.

\section{2 . Implikasi}

Berdasarkan hasil penelitian dan pembahasan maupun kesimpulan di atas, dapat diajukan beberapa saran:1). Guru perlu mengupayakan partisipasi belajar siswa dengan cara melanjutkan pembelajaran menggunakan pendekatan saintifik pada mata pelajaran Pendidikan Agama Islam untuk pertemuan-pertemuan selanjutnya agar siswa tertarik dalam memahami materi yang diberikan dalam proses pembelajaran sehingga partisipasi siswa dapat bertahan bahkan meningkat dan 2). Guru perlu mengupayakan prestasi belajar siswa dengan cara melanjutkan pembelajaran dengan menggunakan pendekatan saintifik pada mata pelajaran Pendidikan Agama Islam untuk pertemuan-pertemuan selanjutnya agar siswa tertarik dalam memahami materi yang diberikan dalam proses pembelajaran sehingga prestasi siswa dapat bertahan bahkan meningkat.

\section{Daftar Pustaka}

Anwar, H. dan Ghozaly, F. (2018). Pendidikan Agama Islam dan Budi Pekerti, Pusat Kurikulum dan Perbukuan Kemendikbud ( Edisi Revisi,cetakan ke-2). Klaten: PT. Macan Jaya Cemerlang.

Arikunto, S. (2009). Dasar-dasar Evaluasi Pendidikan (Edisi Revisi, cetakan 7). Jakarta: Bumi Aksara.

Arikunto, S. (2013). Penelitian Tindakan Kelas. Jakarta : Bumi Aksara.

Depdiknas. (2006). Permendiknas RI Nomor 22 Tahun 2006, tentang Standar Isi Kurikulum Tingkat Satuan Pendidikan. Jakarta.

Depdiknas. (2006). Permendiknas RI nomor 23 Tahun 2006 Tentang Standar Kompetensi Lulusan Kurikulun Tingkat Satuan Pendidikan . Jakarta.

Depdiknas. (2006), Kurikulum Tingkat Satuan Pendidikan. Depdiknas Jakarta

Kemendikbud (2017). Buku Pedoman Guru PAdBP Kelas 6 dan Buku Siswa PAdBP Kelas 6 (Buku PAdBP Terpadu Kurikulum 2013, Jakarta: Kementerian Pendidikan dan Kebudayaan.

Permendiknas, (2006). Peraturan Menteri Pendidikan Nasional nomor 22 tahun 2006 tentang Standar Isi untuk Satuan Pendidikan Dasar dan Menengah. 
Riduwan (2009). Skala Pengukuran Variabel-Variabel Penelitian. Bandung: Alfabeta.

Sanjaya, W. (2007). Strategi Pembelajaran Berorientasi Standar Proses Pendidik. Kencana, Jakarta.

Sudjana, N. (2002). Penilaian Hasil Proses Belajar Mengajar. Bandung: PT. Remaja Rosdakarya. Susilo (2007). Panduan Penelitian Tindakan Kelas. Yogyakarta: Pustaka Book Publlisher.

Tim Balai Pustaka. (2001). Kamus Besar Bahasa Indonesia, Balai Pustaka. Jakarta. 